Research article

urn:1sid:zoobank.org:pub:A2625008-993A-4CB2-8FE7-821C8D8C79B0

\title{
Trogonoptera brookiana mollumar d'Abrera, Doggett \& Parker, 1976 (Lepidoptera: Papilionidae), a subspecies or a synonym?
}

\author{
Chooi-Khim PHON ${ }^{1, *}$, Laurence G. KIRTON ${ }^{2}$ \& Yusoff NORMA-RASHID ${ }^{3}$ \\ ${ }^{1,2}$ Tropical Forest Biodiversity Centre, Forest Research Institute Malaysia, \\ 52109 Kepong, Selangor, Malaysia. \\ ${ }^{1,3}$ Institute of Biological Sciences, Faculty of Science, University of Malaya, \\ 50603 Kuala Lumpur, Malaysia. \\ "Corresponding author: phonchooikhim@frim.gov.my \\ ${ }^{2}$ Email: kirton.frim@gmail.com \\ 32Email: ynorma@um.edu.my

\footnotetext{
${ }^{1}$ urn:1sid:zoobank.org:author:4AC10597-7AA4-401B-8444-3F46E3F0EE44

${ }^{2}$ urn:lsid:zoobank.org:author:40CFD67F-FEF4-4490-9C49-F17CE622DD7C

${ }^{3}$ urn:lsid:zoobank.org:author:9F1F6F6E-85ED-4A88-AFE3-3CAEAF01733E
}

\begin{abstract}
The birdwing butterfly Trogonoptera brookiana (Wallace, 1855) is a well-known conservation icon, yet questions remain about the infraspecific status of regional populations. The eastern Peninsular Malaysian population has been described as the subspecies mollumar d'Abrera, Doggett \& Parker, 1976, but its status as a subspecies distinguishable from the taxon trogon (Vollenhoven, 1860) in Sumatra has been disputed. Wing characters and measurements of specimens from the two regions were therefore examined quantitatively using discriminant function and correspondence analyses. Eastern Peninsular specimens differ on average from Sumatran specimens in having more extensive green, especially in the female. This is reflected in many of the measurements and characters analysed. Females from the Peninsula also have a characteristically blacker upperside ground colour in which the outer areas of both wings barely contrast with the black veins and forewing cell. The extent of these differences enables a reliable differentiation of the females of both regions. The magnitude and consistency of differences are comparable to that between other subspecies of undisputed status. Behavioural differences also exist. The name mollumar therefore merits subspecific status. In addition, we consider the male forms walshi Haugum \& Low, 1982 and walshoides Haugum \& Low, 1982 to be chemically discoloured specimens of trogon rather than biological forms.
\end{abstract}

Keywords. Trogonoptera brookiana trogon, Peninsular Malaysia, Sumatra, taxonomy, morphometrics.

Phon C.-K., Kirton L.G. \& Norma-Rashid Y. 2019. Trogonoptera brookiana mollumar d'Abrera, Doggett \& Parker, 1976 (Lepidoptera: Papilionidae), a subspecies or a synonym? European Journal of Taxonomy 544: 1-25. https://doi.org/10.5852/ejt.2019.544 


\section{Introduction}

Trogonoptera brookiana (Wallace, 1855) is a large birdwing butterfly that ranges from Sumatra through the Riau Archipelago and Peninsular Malaysia to Borneo. A related species, T. trojana (Staudinger, 1889), which is sometimes considered a subspecies of T. brookiana, occurs further east on the island of Palawan. Trogonoptera brookiana exhibits morphological variation across its range, usually in the female sex, and as a result several subspecies have been described. The males of some of these subspecies puddle, sometimes in large monospecific aggregations along forest streams and rivers (Tsukada \& Nishiyama 1982; Panchen 1980), making them very conspicuous and easy to observe. The birdwing is therefore very iconic, featuring on stamps, artwork and promotional material for tourism. It is also the subject of ecotourism in some forest areas (Phon et al. 2011).

The birdwing is also a species of conservation importance that is listed under CITES Appendix II (CITES 2017). It faces ongoing loss and degradation of its forest habitat (Phon et al. 2011) and is sought after by commercial dealers (Kirton 1991; Phon \& Kirton 2009). Peninsular Malaysia is unusual in having two subspecies that occur in different habitats. The better-known subspecies, T. b. albescens (Rothschild, 1895), occurs on the central west of the Titiwangsa Mountain Range in the Peninsula, and a lesserknown subspecies named T. b. mollumar d'Abrera, Doggett \& Parker, 1976 occurs on the north-central and southern plains of the east (Tsukada \& Nishiyama 1982; Corbet \& Pendlebury 1992; Kirton 2014; Fig. 1) where forest is under great pressure from land conversion to agriculture. The iconic character of this birdwing, however, gives it the potential to be a flagship species for conservation of the habitats in which it occurs.

Despite being a well-known and iconic species of conservation importance, there remain questions about the taxonomy of the birdwing's geographically separate populations, particularly the subspecific status of the eastern Peninsular Malaysian population. This population, which occurs from eastern Johor to southernmost Pahang and more rarely from central to southern Terengganu, does not appear to interbreed with the subspecies albescens on the western side of the central mountain range (Fig. 1). It was originally regarded by Corbet \& Pendlebury (1956) as subspecies trogon (Vollenhoven, 1860), the subspecies described from Sumatra (Fig. 1), but was later described as a new subspecies, mollumar d'Abrera, Doggett \& Parker, 1976. However, Haugum \& Low (1982) disputed the reliability of the characters used and the subspecific status of mollumar, treating it only as a locality form of trogon without formally synonymising it. Subsequently, Eliot in Corbet \& Pendlebury (1992), synonymised mollumar with trogon, probably based on Haugum and Low's views. Despite this, Matsuka (2001) and Ohya (in Matsuka 2001) retained usage of mollumar as a subspecies. In response to Haugum \& Low (1982), d'Abrera (2003) argued against synonymy and formally reinstated mollumar as a subspecific taxon.

d'Abrera et al. (1976) used seven characters on the wings of males and three on the wings of females to differentiate between mollumar and trogon, in addition to differences in the male genitalia. These characters are as follows:

1) a more extensive green discal area on the hindwing upperside in male mollumar, extending more than halfway from the base of the hindwing to the dorsum;

2) a noticeably convex distal margin of the green disc on the hindwing upperside in male mollumar, which is either straight or concave in male trogon;

3) green suffused scaling just above vein 7 on the hindwing upperside in male mollumar, which is usually absent or weakly developed in male trogon;

4) a more bowed hindwing vein 8 close to the costa in male mollumar;

5) a less bowed hindwing vein 7 along its length in male mollumar;

6) a hindwing apex that is more sharply angled away from the costa in male mollumar; 
7) the absence of a scallop or incurved margin at the end of the hindwing costa between veins 7 and 8 in male mollumar, which is present in male trogon;

8) a more extensive green discal area on the hindwing upperside in female mollumar, covering more than half of the area of the hindwing;

9) a better developed whitish sub-apical area on the forewing upperside in female mollumar;

10) better developed white sub-marginal spots on the hindwing upperside in female mollumar.

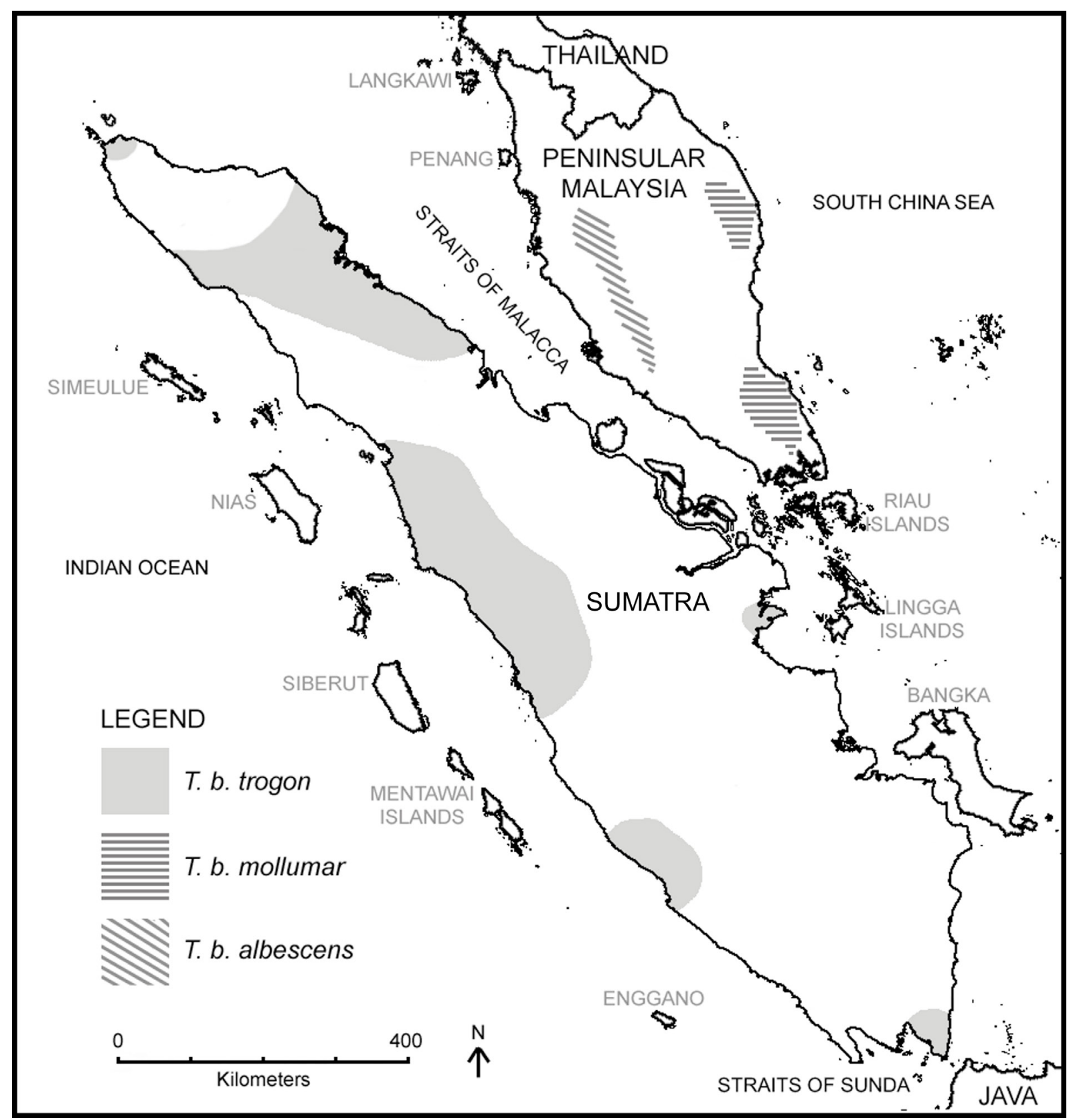

Fig. 1. Distribution map of Trogonoptera brookiana (Wallace, 1855) subspecies albescens (Rothschild, 1895), mollumar d'Abrera, Doggett \& Parker, 1976 and trogon (Vollenhoven, 1860). Ranges are based on localities given in specimen labels and the literature, where georeferencing was possible. 
Haugum \& Low (1982) disagreed with almost all the differences described by d'Abrera et al. (1976). They concluded that the males do not differ and that the females are almost indistinguishable, but likely to have a darker ground colour and an extended green discal area on the hindwing. They stated that the characters described for mollumar could also be found in some specimens of trogon, and that d'Abrera et al. (1976) may have examined too few specimens of trogon to make a valid comparison. Haugum and Low's sample size is difficult to determine accurately because the number of specimens that was stated as examined in the text differs somewhat from the number listed in their section on material examined. Assuming the latter is more reliable, they examined 212 Sumatran males, only 10 Sumatran females, and very few specimens of either sex from Peninsular Malaysia ( 3 males and 4 females). The number of specimens examined by d'Abrera et al. (1976) was not stated.

Previous attempts to diagnose character differences between the subspecies trogon and the nominal taxon mollumar have been limited by inadequate examples of females of trogon and both sexes of mollumar (d'Abrera et al. 1976; Haugum \& Low 1982). In addition, the characters used are sometimes difficult to apply objectively because they are based on wing or vein shape and the extent and size of wing markings, which require subjective judgement. In this study, we examine wing characters quantitatively using measurements, ratios and scores for males and females from Sumatra and the Peninsula. The sample represents the largest number of females from Sumatra and of both sexes from the Peninsula examined thus far. We analyse to what extent the populations differ from each other in the male and female, and whether there are characters that consistently or almost always differentiate them. Based on the analysis, we discuss whether the nominal taxon mollumar merits subspecific status.

Recognising and defining subspecies is important because it provides names to distinct populations that have their own morphological and genetic characteristics. These names provide greater awareness of the need for conservation of such populations.

\section{Material and methods}

We examined specimens and photographs of 188 males and 17 females from Sumatra, and 22 males and 18 females from Johor, southeastern Pahang and Terengganu in Peninsular Malaysia. Specimens examined were from the following collections:

$\begin{array}{ll}\text { Chong-Arshad }= & \text { The joint private collection of Chow-Yang Chong and Sabri John Arshad } \\ \text { FRIM } & \text { Entomological Reference Collection of the Forest Research Institute Malaysia, } \\ & \text { Kepong, Malaysia }\end{array}$

Specimens from MCZ, MZB, ZRC, Chong-Arshad and Kirton were examined only in photographs. Several unlabelled specimens, a few damaged specimens and a small bred female were excluded. A few other bred individuals of normal size were included. A specimen in RMNH (ZMA) that is almost 
certainly from Borneo (subsp. brookiana) but labelled as being from Sumatra (Sumatra, Oost Kust, coll. v. d. Bergh, 1905) was also excluded.

Wing pattern morphology was chosen for analysis for practical as well as technical reasons. Differences in the genitalia disputed by Haugum \& Low (1982) and d'Abrera (2003) are irrelevant when small numbers of specimens are dissected, because subspecies do not differ greatly in structural characteristics, and the slight differences that might occur are likely to be obscured by individual variation. Sampling enough tissue for a molecular analysis of T. brookiana presents legal difficulties, since it is a protected species in both Indonesia and Malaysia, and poses technical challenges because sampling would ideally need to be done non-destructively. Furthermore, in many insect groups percentage differences between DNA sequences do not necessarily predict even species boundaries (Cognato 2006). Studies on Asian Papilioninae (Tsao \& Yeh 2008) show that COI sequence divergences between subspecies are generally very slight, and yet the divergence among subspecies of several species was greater than the average divergence between all species.

A selection of wing characters mentioned by d'Abrera et al. (1976) was quantified, that is nos 1-3 and 8 listed above. These characters demonstrate the relative size and extent of the green disc on the hindwing in both sexes (Figs 2A, C, 3A) and its shape in the male (Fig. 3A-E). Other characters mentioned by d'Abrera et al. (1976), that is characters nos 4-7, 9-10 (see above), were omitted because we could not observe sufficient consistency in these characters to be useful. Forewing length of the male and the ground colour of the female (Fig. 2A, C) - characters mentioned by Haugum \& Low (1982) - were also investigated. Haugum \& Low (1982) stated that the forewing length of males of mollumar fell within the norm of trogon, but the non-overlapping ranges they reported contradicted this statement and instead showed the former as being larger. We included two other characters of our own that demonstrate the distal extent of green scaling on the forewing of the female (Fig. 2A-B, D-H). In addition, we quantified characters suggested by C.Y. Chong at a later stage of our study, which demonstrate the extent and location of the green arrow-shaped markings in relation to the dark ground colour of the forewing (Figs 2A, C, 3A). Complete measurement data was available for 13 females and 16 males of each taxon, the sample size of taxa deliberately equalised within sexes to eliminate any bias in the multivariate analysis of numeric data. The specimens were a random subsample without bias to any wing character. Analysis of categorical data was based on a larger data set.

The characters used are defined in Table 1 and are illustrated in Figures 2 and 3. Measurements and scores were generally based on the side right of the specimens and made with a ruler, for physical specimens, or with image analysis software, for specimens photographed against a ruler. The left side was used when damage to the wings on the right side precluded its use. The different methods of measurement are not expected to introduce significant inaccuracies or biases, as the birdwings were large, making differences between individuals relatively large in comparison to the very small differences that may result from the different methods. Ground colour was judged in contrast with the basal half of the forewing cell, which was always virtually black. In this way, a bias due to scale pigment fade as a result of differing specimen ages and differing levels of light exposure was avoided. Fade occurs uniformly across the whole specimen, and the contrast in ground colour could still be seen in relation to each specimen's forewing cell base.

Ratios calculated from the measurement data were analysed by discriminant function analysis to determine the relative strength of the different characters in separating the Sumatran and Peninsular Malaysian populations of each sex. Forewing length was analysed separately using a Mann-Whitney test, since its inclusion in discriminant function analysis resulted in a deviation from multivariate normality and homogeneity of the variance-covariance matrices even after data transformation. 
Table 1 (continued on next page). Character descriptions. Numerators, denominators and scores for categorical data (numerals in parentheses) are illustrated in Figs 1-2.

\begin{tabular}{|c|c|c|c|c|}
\hline No. & $\begin{array}{l}\text { Character } \\
\text { abbreviation }\end{array}$ & Sex & Character & $\begin{array}{l}\text { Calculation or } \\
\text { categorisation }\end{array}$ \\
\hline 1. & FwL & $\lambda$ 우 & $\begin{array}{l}\text { Forewing length }(\mathrm{cm}) \text { measured on the } \\
\text { underside from the base of the forewing } \\
\text { costa to the distalmost margin of the apex. }\end{array}$ & $a b$ \\
\hline 2. & UpHwSp5GrRatio & 후 & $\begin{array}{l}\text { On the hindwing upperside, a ratio formed } \\
\text { by the distance to which the green scaling } \\
\text { in space } 5 \text { reaches at its distal end (d) on } \\
\text { a straight line between the base of the cell } \\
\text { (c) and the end of vein } 6 \text { (e), divided by the } \\
\text { entire length of the straight line. }\end{array}$ & $\mathrm{cd} / \mathrm{ce}$ \\
\hline 3. & UpHwSp4GrRatio & $\widehat{0}$ 우 & $\begin{array}{l}\text { On the hindwing upperside, a ratio formed } \\
\text { by the distance to which the green scaling } \\
\text { in space } 4 \text { reaches at its distal end (g) on a } \\
\text { straight line between the base of vein } 5(\mathrm{f}) \\
\text { and the end of vein } 5(\mathrm{~h}) \text {, divided by the } \\
\text { entire length of the straight line. }\end{array}$ & $\mathrm{fg} / \mathrm{fh}$ \\
\hline 4. & UpHwSp2GrRatio & 하 & $\begin{array}{l}\text { On the hindwing upperside, a ratio formed } \\
\text { by the distance to which the green scaling } \\
\text { in space } 2 \text { reaches at its distal end (i) on a } \\
\text { straight line between the base of the cell } \\
\text { (c) and the end of vein } 3 \text { (j), divided by the } \\
\text { entire length of the straight line. }\end{array}$ & $\mathrm{ci} / \mathrm{cj}$ \\
\hline 5. & UpFwV2GrRatio & $\lambda$ 우 & $\begin{array}{l}\text { On the upperside forewing, on a straight } \\
\text { line intersecting the forewing costa }(\mathrm{k}) \text {, } \\
\text { the inner }(\mathrm{l}) \text { and outer }(\mathrm{m}) \text { edges of the } \\
\text { green marking along vein } 2 \text {, and the termen } \\
\text { (n), a ratio formed by the length of the } \\
\text { green scaling }(\mathrm{lm}) \text { divided by the distance } \\
\text { between its inner edge and the termen }(\mathrm{ln}) \text {. }\end{array}$ & $\operatorname{lm} / \ln$ \\
\hline 6. & UpFwV2BIRatio & o우 & $\begin{array}{l}\text { On the same straight line defined above for } \\
\text { UpFwV2GrRatio, a ratio formed by the } \\
\text { width of the black area between the costa } \\
\text { and the inner edge of the green marking }(\mathrm{kl}) \\
\text { divided by the width of the wing from costa } \\
\text { to termen (kn). }\end{array}$ & $\mathrm{kl} / \mathrm{kn}$ \\
\hline 7. & UpFwV4GrRatio & $\widehat{0}$ 우 & $\begin{array}{l}\text { A ratio similar to UpFwV2GrRatio on the } \\
\text { forewing upperside but along vein } 4 \text {. }\end{array}$ & $\mathrm{pq} / \mathrm{pr}$ \\
\hline
\end{tabular}


Table 1 (continued). Character descriptions. Numerators, denominators and scores for categorical data (numerals in parentheses) are illustrated in Figs 1-2.

\begin{tabular}{|c|c|c|c|c|}
\hline No. & $\begin{array}{l}\text { Character } \\
\text { abbreviation }\end{array}$ & Sex & Character & $\begin{array}{l}\text { Calculation or } \\
\text { categorisation }\end{array}$ \\
\hline 8. & UpFwV4BIRatio & $\hat{0}$ 우 & $\begin{array}{l}\text { A ratio similar to UpFwV2BIRatio on the } \\
\text { forewing upperside but along vein } 4 \text {. }\end{array}$ & op / or \\
\hline 9. & GColour & 우 & $\begin{array}{l}\text { On the upperside of both wings, the } \\
\text { ground colour of the dark distal areas, in } \\
\text { comparison to the black basal half of the } \\
\text { forewing cell. }\end{array}$ & $\begin{array}{l}\text { (1) Brown, or (2) } \\
\text { black (as black or } \\
\text { nearly as black as } \\
\text { the cell) }\end{array}$ \\
\hline 10. & UpFwV7Gr & q & $\begin{array}{l}\text { On the forewing upperside, the density of } \\
\text { postdiscal green scales just below vein } 7 \text {. }\end{array}$ & $\begin{array}{l}\text { (1) None, (2) sparse, } \\
\text { or (3) dense }\end{array}$ \\
\hline 11. & UnFwSp4Gr & 우 & $\begin{array}{l}\text { On the forewing underside, the density and } \\
\text { extent of discal green scales in space } 4 \text {. }\end{array}$ & $\begin{array}{l}\text { (1) None, (2) sparse, } \\
\text { or forming a (3) } \\
\text { broken patch or (4) } \\
\text { dense patch }\end{array}$ \\
\hline 12. & UpHwGrDisc & o & $\begin{array}{l}\text { On the hindwing upperside, the shape of the } \\
\text { distal margin of the green disc. }\end{array}$ & $\begin{array}{l}\text { (0) Indented, (1) } \\
\text { straight, (2) convex }\end{array}$ \\
\hline 13. & UpHwSp7Gr & $\hat{0}$ & $\begin{array}{l}\text { On the hindwing upperside, the density of } \\
\text { discal green scales in space } 7 \text { just above } \\
\text { vein } 7 \text {. }\end{array}$ & $\begin{array}{l}\text { (0) None, (2) sparse, } \\
\text { or (3) dense }\end{array}$ \\
\hline
\end{tabular}

Characters in nos 2, 3, 4, 12 and 13 are quantified from d'Abrera et al. 1976. Characters in nos 1 and 9 are quantified from Haugum \& Low 1982. Characters in nos 5, 6, 7 and 8 are suggested by C.Y. Chong. The present authors suggested characters in nos 10 and 11.

Simple correspondence analysis was used for the categorical characters of each sex, to explore their association with each other and with the Sumatran and Peninsular Malaysian populations. For characters that formed stronger species associations in the correspondence analysis, chi-square tests were used to determine whether they were significant, with the significance level taken as the normal $\alpha$ value of 0.05 divided by the number of tests (Bonferroni correction). Discriminant function analysis was conducted using SPSS ${ }^{\circledR} 20.0 .0$. All other analyses were conducted using Minitab ${ }^{\circledR} 18.1$.

\section{Results}

\section{Analyses of characters}

\section{Females}

There is no significant difference in median forewing length of females (Mann-Whitney $\mathrm{W}=188.0$, $\mathrm{P}=0.537)$, which measure $8.00 \mathrm{~cm}$ (range $7.40-8.80 \mathrm{~cm})$ and $7.85 \mathrm{~cm}(7.30-8.70 \mathrm{~cm}$ ) respectively in Peninsular and Sumatran females that we examined. A summary of the ratio data for female birdwings from Sumatra and Peninsular Malaysia is shown in Table 2. Peninsular females have on average more extensive green scaling relative to black ground colour on both the forewing and hindwing, compared to 
Sumatran females (Figs 2A, C, 4A-B). The ranges of the ratios of green on the forewing do not overlap between populations, but they overlap on the hindwing, as do the ratios of black.

Using discriminant function analysis with cross-validation, the resulting canonical discriminant function has an eigenvalue of 4.205 and a high canonical correlation of 0.899 and is significant (Wilk's Lambda $=0.192, \chi^{2}=33.819, \mathrm{df}=7, \mathrm{P}<0.001$ ). The standardised canonical discriminant function was used to examine the relative strength of each character (Table 3). Cross-validation results in $88.5 \%$ of the specimens being classified correctly to their original geographic regions by the classification functions for the Peninsular and Sumatran specimens (Table 3). The group centroid from the unstandardised coefficients (Table 3) is positive and negative 1.970 for Peninsular and Sumatran females, respectively. Tests of equality of group means in the discriminant function analysis reveal four out of seven characters that differ significantly between populations (Table 2). Of these, the extent of green in space 4 of the

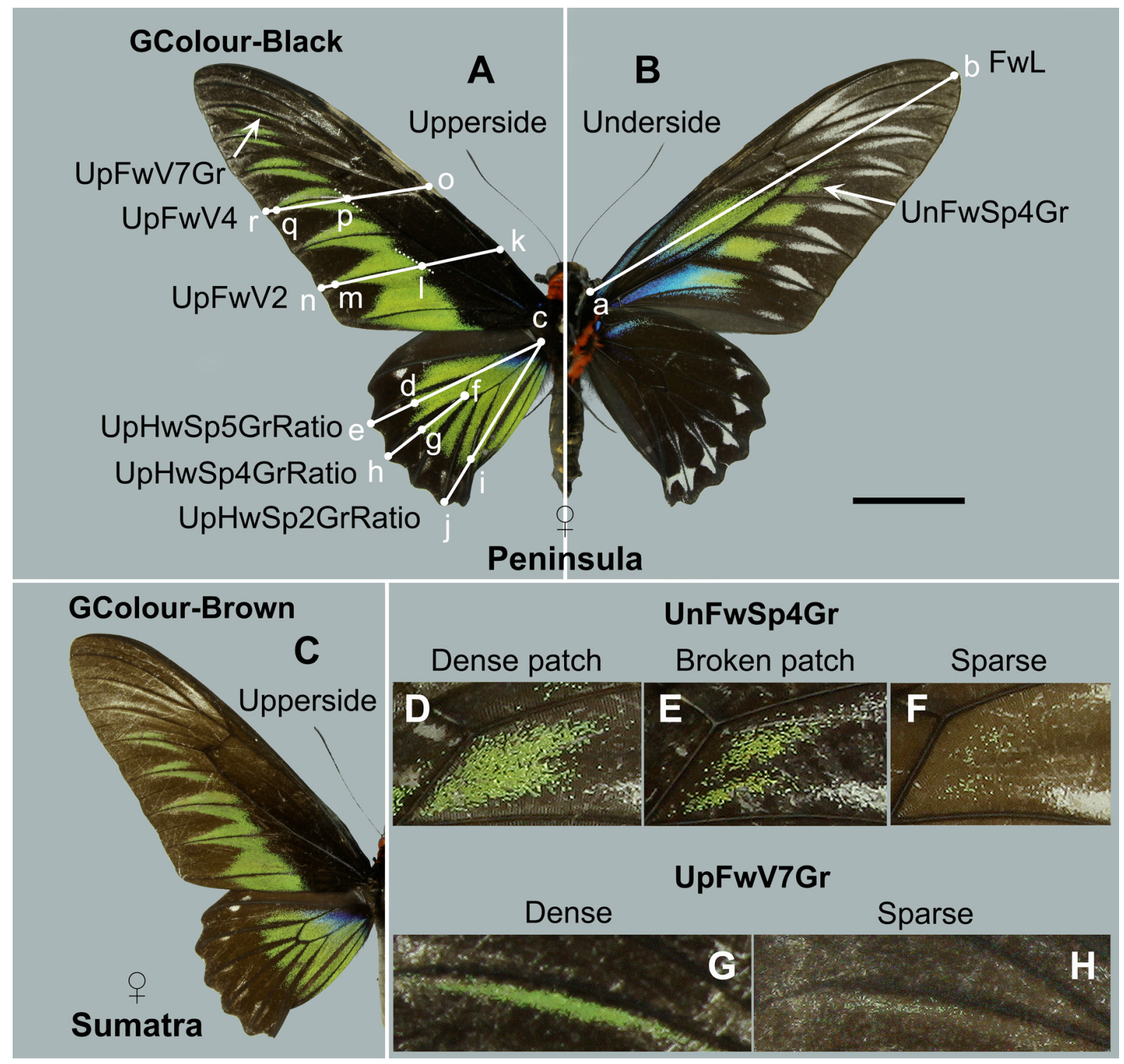

Fig. 2. Illustrations of measurements used for both sexes, and categorical characters used for females. Scale bar: A-C $=2.00 \mathrm{~cm}$. See Table 1 for descriptions. 
hindwing upperside (UpHwSp4GrRatio) and along vein 2 of the forewing upperside (UpFwV2GrRatio) have the greatest coefficients in the standardised canonical discriminant function and thus the greatest discriminatory impact between the two populations (Table 3). The extent of green and black along vein 4 of the forewing upperside (UpFwV4GrRatio and UpFwV4BlRatio, respectively) has a lower discriminatory impact in the standardised canonical discriminant function (Table 3 ) but is significantly different between populations (Table 2).

Table 4 summarises the data for the categorical characters of females, and Figure 5 shows a twodimensional plot of the first two components of simple correspondence analysis. Sumatran and Peninsular specimens are distributed on opposite ends of the two-dimensional plot, primarily because of the first component. Sumatran specimens are strongly associated with a brown ground colour (GColour_Brown; Figs 2C, 4B), less green scaling in space 4 of the forewing underside (UnFwSp4Gr_None or Sparse; Fig. 2F), and less green scaling just below vein 7 on the forewing upperside (UpFwV7Gr_None or _Sparse; Figs 2C, H, 4B). Peninsular specimens are strongly associated with a black ground colour (GColour_Black; Figs 2A, 4A), a dense and complete or broken patch of green scales in space 4 of the forewing underside (UnFwSp4Gr_BrokenPatch or_DensePatch; Fig. 2B, D-E), and dense green scaling just below vein 7 on the forewing upperside (UpFwV7Gr_Dense; Figs 2A, G, 4A). There is more scatter in the characters on the Sumatran end of the biplot (Fig. 5). Except for one Sumatran female, the difference in ground colour is sufficiently distinct in the two populations (Table 4). Among females from Sumatra, 94\% are categorised as brown (Figs 2C, 4B), while all Peninsular Malaysian females are categorised as black (Figs 2A, 4A). Differences between the ground colour, the green scaling below vein 7 on the forewing upperside and in space 4 on the forewing underside are significant (Chi square test, Table 4). Dense green scaling below vein 7 occurs in $89 \%$ of the Peninsular females compared to $29 \%$ of the Sumatran females. All Peninsular females examined have a dense or broken patch of green scales in

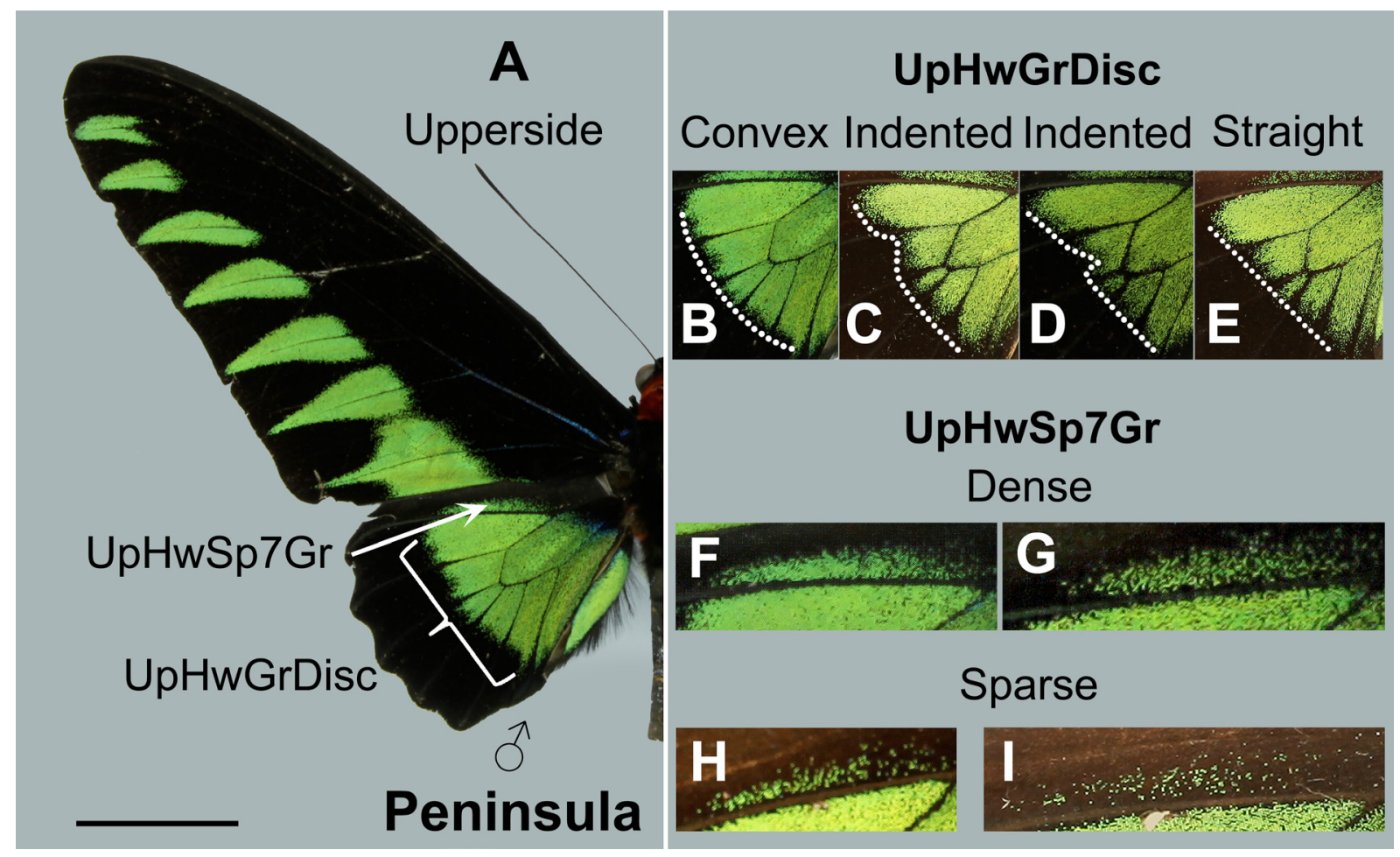

Fig. 3. Illustrations of categorical characters in males. Scale bar $=2.00 \mathrm{~cm}$. See Table 1 for descriptions. 
Table 2. Ratio characters for Sumatran and Peninsular Malaysian females (mean \pm standard error, and range).

\begin{tabular}{lcccc}
\hline Character abbreviation & Sumatra & Peninsular Malaysia & $\mathbf{F}_{\mathbf{1 , 2 4}}$ & P \\
\hline UpHwSp4GrRatio * & $0.43 \pm 0.02$ & $0.52 \pm 0.01$ & 18.565 & $<0.001$ \\
& $(0.35-0.55)$ & $(0.45-0.62)$ & & \\
UpHwSp2GrRatio & $0.71 \pm 0.01$ & $0.71 \pm 0.02$ & 0.027 & 0.870 \\
& $(0.64-0.81)$ & $(0.59-0.78)$ & & \\
UpHwSp5GrRatio & $0.67 \pm 0.01$ & $0.71 \pm 0.01$ & 3.913 & 0.060 \\
& $(0.56-0.75)$ & $(0.58-0.78)$ & & \\
UpFwV2GrRatio * & $0.84 \pm 0.01$ & $0.90 \pm 0.00$ & 47.225 & $<0.001$ \\
& $(0.80-0.87)$ & $(0.88-0.92)$ & & \\
UpFwV2B1Ratio & $0.44 \pm 0.01$ & $0.42 \pm 0.01$ & 5.354 & 0.030 \\
& $(0.41-0.48)$ & $(0.36-0.45)$ & & \\
UpFwV4GrRatio * & $0.80 \pm 0.01$ & $0.89 \pm 0.00$ & 39.077 & $<0.001$ \\
& $(0.69-0.85)$ & $(0.86-0.91)$ & & \\
UpFwV4BIRatio * & $0.52 \pm 0.01$ & $0.48 \pm 0.01$ & 12.864 & 0.001 \\
\hline
\end{tabular}

$\mathrm{N}=13$ each from Sumatra and Peninsular Malaysia. * Significantly different between regions at $\alpha=0.007$ (Bonferroni correction).

Table 3. Coefficients and constants for each ratio character in the cross-validated canonical discriminant and classification functions of female birdwings from Sumatra and Peninsular Malaysia.

\begin{tabular}{lcccc}
\hline \multirow{2}{*}{ Characters } & \multicolumn{2}{c}{ Canonical discriminant function } & \multicolumn{2}{c}{ Classification function } \\
\cline { 2 - 5 } & Standardised & Unstandardised & Peninsular & Sumatran \\
\hline Constant & & -34.681 & -1923.349 & -1786.687 \\
UpHwSp4GrRatio & 0.757 & 13.282 & 121.231 & 68.893 \\
UpFwV2GrRatio & 0.670 & 29.477 & 1824.531 & 1708.376 \\
UpHwSp2GrRatio & -0.376 & -6.457 & 165.830 & 191.273 \\
UpFwV4GrRatio & 0.319 & 9.201 & 719.110 & 682.854 \\
UpFwV2B1Ratio & 0.231 & 9.404 & 593.061 & 556.004 \\
UpFwV4B1Ratio & -0.212 & -7.507 & 1336.465 & 1366.045 \\
UpHwSp5GrRatio & 0.050 & -1.008 & 697.522 & 701.493 \\
\hline
\end{tabular}


Table 4. Numbers and percentages (in parentheses) of females from Sumatra and Peninsular Malaysia with each categorical character.

\begin{tabular}{|c|c|c|c|c|c|c|c|c|c|}
\hline \multirow{3}{*}{ Region } & \multicolumn{9}{|c|}{ Characters (abbreviated) and categories } \\
\hline & \multicolumn{2}{|c|}{ GColour: } & \multicolumn{3}{|c|}{ UpFwV7Gr \# } & \multicolumn{4}{|c|}{ UnFwSp4Gr* } \\
\hline & Brown & Black & None & Sparse & Dense & None & Sparse & $\begin{array}{c}\text { Broken } \\
\text { patch }\end{array}$ & $\begin{array}{c}\text { One dense } \\
\text { patch }\end{array}$ \\
\hline Sumatra & $\begin{array}{c}16 \\
(94.12)\end{array}$ & $\begin{array}{c}1 \\
(5.88)\end{array}$ & $\begin{array}{c}4 \\
(23.53)\end{array}$ & $\begin{array}{c}8 \\
(47.06)\end{array}$ & $\begin{array}{c}5 \\
(29.41)\end{array}$ & $\begin{array}{c}3 \\
(17.65)\end{array}$ & $\begin{array}{c}12 \\
(70.59)\end{array}$ & $\begin{array}{c}2 \\
(11.76)\end{array}$ & $\begin{array}{c}0 \\
(0.00)\end{array}$ \\
\hline $\begin{array}{l}\text { Peninsular } \\
\text { Malaysia }\end{array}$ & $\begin{array}{c}0 \\
(0.00)\end{array}$ & $\begin{array}{c}18 \\
(100.00)\end{array}$ & $\begin{array}{c}0 \\
(0.00)\end{array}$ & $\begin{array}{c}2 \\
(11.11)\end{array}$ & $\begin{array}{c}16 \\
(88.89)\end{array}$ & $\begin{array}{c}0 \\
(0.00)\end{array}$ & $\begin{array}{c}0 \\
(0.00)\end{array}$ & $\begin{array}{c}15 \\
(83.33)\end{array}$ & $\begin{array}{c}3 \\
(16.67)\end{array}$ \\
\hline
\end{tabular}

$\mathrm{N}=17$ (Sumatra) and 18 (Peninsular Malaysia). $\alpha=0.017$ after Bonferroni correction. ${ }^{\ddagger}$ Chi Square $=31.207, \mathrm{df}=1$, $\mathrm{p}<0.001 .{ }^{\#}$ Chi Square $=13.344, \mathrm{df}=2, \mathrm{p}=0.001 .{ }^{*}$ Chi Square $=27.935, \mathrm{df}=3, \mathrm{p}<0.001$.

space 4 of the forewing underside (Fig. 2B, D-E), whereas only $12 \%$ of Sumatran females have broken patches (Fig. 2E), 71\% have sparse scaling (Fig. 2F) and 18\% have none.

\section{Males}

Peninsular and Sumatran males examined have significantly different median forewing lengths of $8.05 \mathrm{~cm}$ (range 6.80-8.40 cm) and $7.38 \mathrm{~cm}$ (range 6.45-7.80 cm), respectively (Mann-Whitney $\mathrm{W}=354.50$, $\mathrm{P}<0.001)$. Table 5 summarises the ratio data for male birdwings from the Peninsula and Sumatra. On average, Peninsular males have more green scaling on both the forewing and hindwing (Figs 3A, 4C), although overlapping ranges occur in all characters.

The cross-validated discriminant function is significant (Wilk's Lambda $=0.266, \chi^{2}=35.112, \mathrm{df}=7$, $\mathrm{P}<0.001$ ) with an eigenvalue of 2.762 and canonical correlation value of 0.857 . The group centroid for Peninsular and Sumatran males is positive and negative 1.609, respectively, in the unstandardised canonical discriminant function (Table 6). In the cross-validation, $87.5 \%$ of specimens are classified to their correct region by the classification functions for the Peninsular and Sumatran specimens (Table 6). The relative extent of black along vein 4 of the forewing upperside (UpFwV4BIRatio) has the most impact in discriminating between populations, as seen in its high coefficient in the standardised canonical discriminant function (Table 6), but it does not differ significantly between geographical regions in the tests of equality of the group means (Table 5). It is followed in importance by the extent of green in spaces 4 (UpHwSp4GrRatio) and 5 (UpHwSp5GrRatio) of the hindwing upperside (Table 6), both of which are significant in the tests of equality of the group means (Table 5). The extent of green along vein 2 of the forewing upperside (UpFwV2GrRatio) is also significant (Table 5) although fifth in importance in the standardised canonical discriminant function (Table 6).

Data for the categorical characters is summarised in Table 7, and Figure 6 shows the first two components of the correspondence analysis. Peninsular Malaysian and Sumatran males are more scattered in the graph compared to females, but males from the Peninsula are still located on the right and males from Sumatra on the left (Fig. 6). Sumatran males are most associated with a straight green disc on the hindwing upperside (UpHwGrDisc_Straight; Figs 3E, 4D) and little or no green scales in space 7 of the hindwing upperside (UpHwSp7Gr_None and_Sparse; Figs 3H-I, 4D). Peninsular males are most 

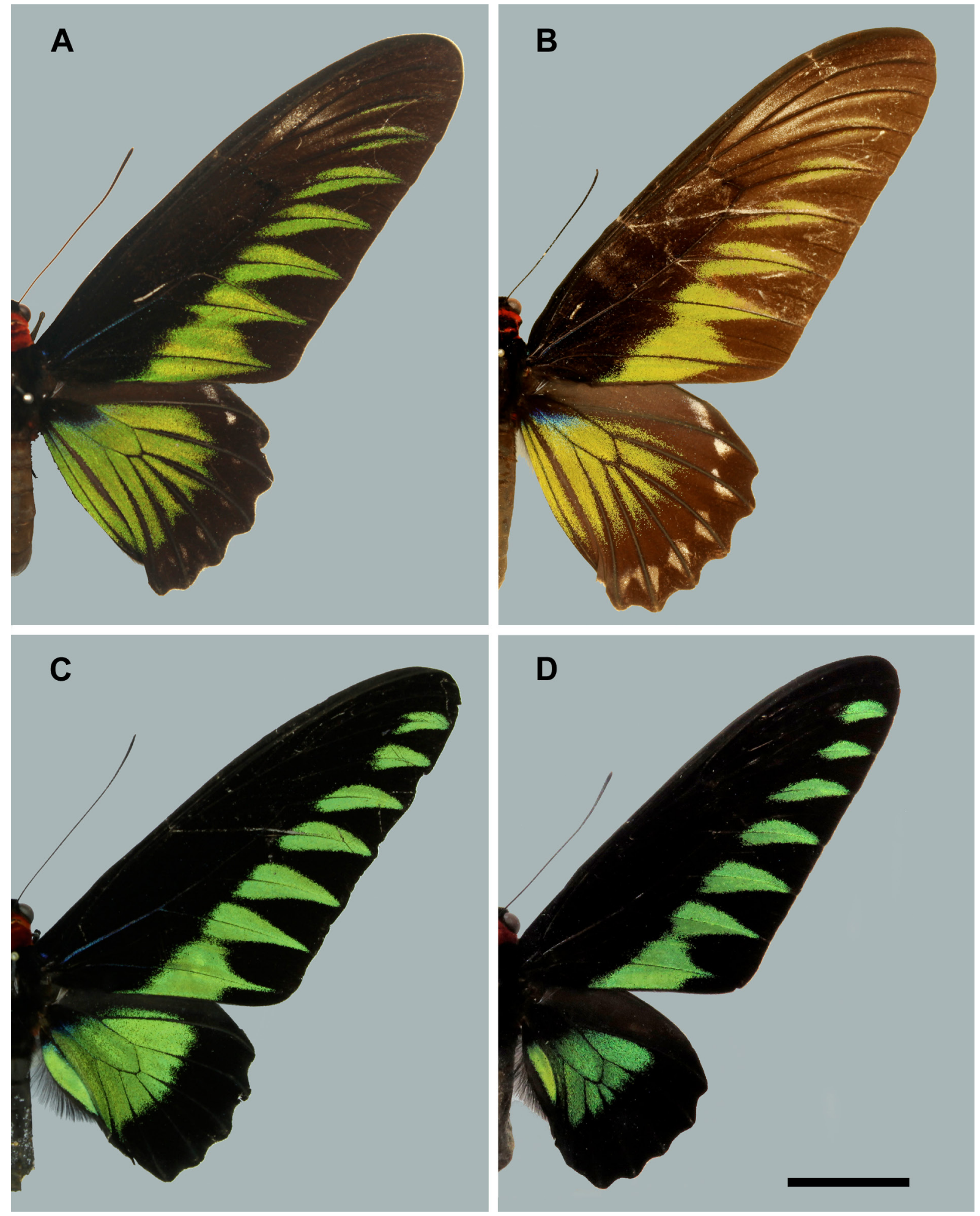

Fig. 4. Females (top) and males (bottom) of Trogonoptera brookiana mollumar d'Abrera, Doggett \& Parker, 1976 (A and C) and T. b. trogon (Vollenhoven, 1860) (B and D). Scale bar $=2.00 \mathrm{~cm}$. 
associated with a convex and indented green hindwing disc (UpHwGrDisc_Convex and Indented; Figs 3B-D, 4C) and with dense green scales in space 7 of the hindwing upperside (UpHwSp7Gr_Dense; Figs $3 \mathrm{~A}, 3 \mathrm{~F}-\mathrm{G}, 4 \mathrm{C})$, but they share these characters to some extent with Sumatran males. Differences between the populations are significant for both characters (Chi Square test, Table 7).

\section{Synthesis of character analyses}

The discriminant function analysis shows a significant difference between populations in both sexes when all characters are considered. Individual variables that differ significantly between populations in the univariate comparisons of the present study (Tables 2, 5) are not always variables that make an important contribution towards discrimination of the populations when all variables are considered in the multivariate dimension (Tables 3,6 ). In the females examined, these variables are the extent of green and black measured on vein 4 (UpFwV4GrRatio and UpFwV4BIRatio, respectively; Fig. 2A), which are fourth and sixth in importance, respectively, in the seven-variable discriminant function (Table 3). In males, the extent of green on veins 2 and 4 (UpFwV2GrRatio and UpFwV4GrRatio, respectively; Figs 2A, 3A), though significant in univariate tests, are the fifth and sixth terms, respectively, in the function (Table 6).

Conversely, some variables in the present study that hardly differ in a univariate comparison (Tables $2,5)$ between populations make an important contribution towards discrimination in the multivariate dimension (Tables 3,6). Such variables are the ratio of green in space 2 of the hindwing upperside (UpHwSp2GrRatio; Fig. 2A) in the female, which is the third term in the function (Table 3), and the extent of black measured on vein 4 of the forewing upperside (UpFwV4B1Ratio) in the male (Figs 2A, $3 \mathrm{~A}$ ), which is the first term in the function (Table 6). These outcomes show that while some characters

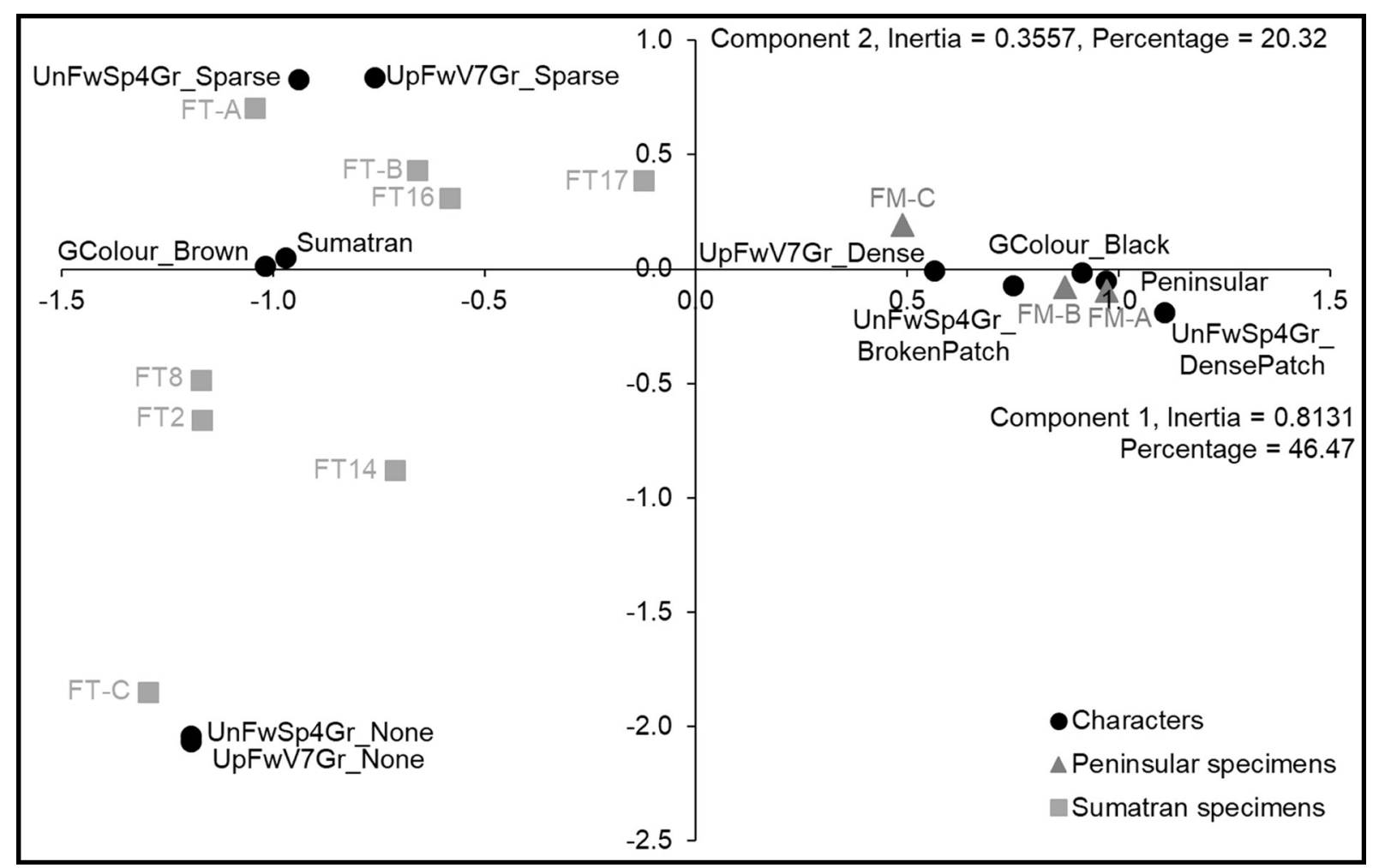

Fig. 5. Two-dimensional plot of correspondence analysis components 1 and 2 for females. Specimens with identical coordinates are grouped together (e.g., FT-A = female, Sumatra, group A; FM-A = female, Peninsular Malaysia, group A). 
Table 5. Ratio characters for Sumatran and Peninsular Malaysian males (mean \pm standard error, and range).

\begin{tabular}{|c|c|c|c|c|}
\hline Character abbreviation & Sumatra & $\begin{array}{c}\text { Peninsular } \\
\text { Malaysia }\end{array}$ & $F_{1,30}$ & $\mathbf{P}$ \\
\hline UpHwSp4GrRatio * & $\begin{array}{c}0.21 \pm 0.02 \\
(0.12-0.36)\end{array}$ & $\begin{array}{l}0.32 \pm 0.01 \\
(0.22-0.44)\end{array}$ & 25.809 & $<0.001$ \\
\hline UpHwSp2GrRatio & $\begin{array}{l}0.63 \pm 0.01 \\
(0.60-0.68)\end{array}$ & $\begin{array}{l}0.67 \pm 0.01 \\
(0.61-0.78)\end{array}$ & 8.000 & 0.008 \\
\hline UpHwSp5GrRatio * & $\begin{array}{l}0.62 \pm 0.01 \\
(0.56-0.70)\end{array}$ & $\begin{array}{l}0.66 \pm 0.01 \\
(0.59-0.70)\end{array}$ & 12.214 & 0.001 \\
\hline UpFwV2GrRatio * & $\begin{array}{l}0.90 \pm 0.01 \\
(0.85-0.93)\end{array}$ & $\begin{array}{l}0.93 \pm 0.00 \\
(0.91-0.95)\end{array}$ & 19.957 & $<0.001$ \\
\hline UpFwV2B1Ratio & $\begin{array}{l}0.51 \pm 0.00 \\
(0.48-0.54)\end{array}$ & $\begin{array}{l}0.51 \pm 0.00 \\
(0.48-0.55)\end{array}$ & 0.385 & 0.540 \\
\hline UpFwV4GrRatio * & $\begin{array}{l}0.90 \pm 0.01 \\
(0.86-0.95)\end{array}$ & $\begin{array}{l}0.93 \pm 0.00 \\
(0.89-0.96)\end{array}$ & 15.569 & $<0.001$ \\
\hline UpFwV4B1Ratio & $\begin{array}{c}0.55 \pm 0.01 \\
(0.51-0.60)\end{array}$ & $\begin{array}{l}0.55 \pm 0.00 \\
(0.52-0.60)\end{array}$ & 0.167 & 0.686 \\
\hline
\end{tabular}

$\mathrm{N}=16$ each from Sumatra and Peninsular Malaysia. ${ }^{*}$ Significantly different between regions at $\alpha=0.007$ (Bonferroni correction).

are useful when examined as the sole character of differentiation between the two populations, they do not hold as true when a multi-character approach is used in separating the populations. And while some variables are useful in a multi-character approach, they can be much less useful when used on their own.

Variables that are both significant in the univariate tests and make important contributions in the discriminant function can be considered more reliable characters to use either on their own or in conjunction with other characters. These are the extent of green in space 4 of the hindwing upperside (UpHwSp4GrRatio) and along vein 2 of the forewing upperside (UpFwV2GrRatio) in the female (Fig. 2A), which are the first and second terms respectively in the function (Table 3), and the extent of green in spaces 4 (UpHwSp4GrRatio) and 5 (UpHwSp5GrRatio) of the hindwing upperside in the male (Figs 2A, 3A), which are the second and third terms respectively in the function (Table 6).

Among the categorical characters used in the female, the ground colour (GColour) of the distal area of the upperside of both wings is the most distinguishing character (Figs 2A, C, 4A-B, 5; Table 4), being almost always paler and browner than the forewing cell in Sumatran specimens (Figs 2C, 4B, 5; Table 4). The only exception seen is a specimen that is otherwise typical of the Sumatran population in all other respects. The green scaling in space 4 of the forewing underside (UnFwSp4Gr) usually is also a reliable character, generally forming a broken or complete patch in Peninsular specimens (Figs 2B, D-E, 5; Table 4), or being absent or reduced to sparse scales in Sumatran specimens (Figs 2F, 5; Table 4). The green scaling below vein 7 on the forewing upperside ( $\mathrm{UpFwV7Gr),} \mathrm{which} \mathrm{is} \mathrm{generally} \mathrm{reduced} \mathrm{in}$ Sumatran females, is useful though a much less reliable character because of variation in the Sumatran population (Figs 2C, H, 4B, 5; Table 4). The greater variation in Sumatran specimens results in a greater scatter in the characters on the Sumatran end of the biplot in the correspondence analysis (Fig. 5). Categorical characters used in the male are less useful in differentiating the Sumatran and Peninsular 
Table 6. Coefficients and constants for each ratio character in the cross-validated canonical discriminant and classification functions of male birdwings from Sumatra and Peninsular Malaysia.

\begin{tabular}{lcccc}
\hline \multirow{2}{*}{ Characters } & \multicolumn{2}{c}{ Canonical discriminant function } & \multicolumn{2}{c}{ Classification function } \\
\cline { 2 - 5 } & Standardised & Unstandardised & Peninsular & Sumatran \\
\hline Constant & & -14.537 & -2071.954 & -2025.168 \\
UpFwV4B1Ratio & -1.013 & -46.773 & 283.549 & 434.082 \\
UpHwSp4GrRatio & 0.975 & 16.012 & -760.562 & -812.094 \\
UpHwSp5GrRatio & 0.628 & 17.990 & 476.427 & 418.529 \\
UpHwSp2GrRatio & -0.456 & -13.034 & 789.090 & 831.039 \\
UpFwV2GrRatio & 0.361 & 17.893 & 1329.498 & 1271.911 \\
UpFwV4GrRatio & 0.322 & 15.978 & 1772.206 & 1720.781 \\
UpFwV2B1Ratio & 0.084 & 4.208 & 993.803 & 980.259 \\
\hline
\end{tabular}

Table 7. Numbers and percentages (in parentheses) of males with each categorical character from Sumatra and Peninsular Malaysia.

\begin{tabular}{lcccccc}
\hline \multirow{3}{*}{ Region } & \multicolumn{5}{c}{ Characters (abbreviated) and categories } \\
\cline { 2 - 7 } & \multicolumn{3}{c}{ UpHwGrDisc ${ }^{*}$} & \multicolumn{3}{c}{ UpHwSp7Gr* } \\
\cline { 2 - 7 } Convex & Indented & Straight & None & Sparse & Dense \\
\hline \multirow{2}{*}{ Sumatra } & 47 & 35 & 106 & 27 & 94 & 67 \\
& $(25.00)$ & $(18.62)$ & $(56.38)$ & $(14.36)$ & $(50.00)$ & $(35.64)$ \\
Peninsular & 13 & 7 & 2 & 0 & 5 & 17 \\
Malaysia & $(59.09)$ & $(31.82)$ & $(9.09)$ & $(0.00)$ & $(22.73)$ & $(77.27)$ \\
\hline
\end{tabular}

$\mathrm{N}=188$ (Sumatra) and 22 males (Peninsular Malaysia). $\alpha=0.025$ (Bonferroni correction). ${ }^{\#}$ Chi Square $=18.293$, $\mathrm{df}=2, \mathrm{p}<0.001 .{ }^{*}$ Chi Square $=14.802, \mathrm{df}=2, \mathrm{p}=0.001$.

populations, even though significant differences occur between them (Fig. 6; Table 7). This is because of an even greater variation in the Sumatran males.

Females differ more than males between the two populations. The most diagnostic characters in the female are the ground colour of the distal areas of both wings on the upperside in relation to the forewing cell (Fig. 5; Table 4), the extent of green in space 4 of the hindwing upperside and the extent of green along vein 2 of the forewing upperside (Tables 2-3). Males of the two populations only differ on average but cannot be reliably distinguished. The extents of the green markings on the uppersides of both wings (Tables 5-6) and consequently the shape of the discal margin of the green hindwing patch (Table 7) are the most indicative characters in the male.

\section{Comparative extent of morphological differences in other subspecies}

Differences between the various subspecies of brookiana are generally slight. They are based on the females, because the males resemble each other and differ very little. Similar cases of subspecies based 
mainly on the female sex are found in other butterfly species, such as Troides aeacus (C. \& R. Felder, 1860), in which the mainland subspecies aeacus, the Taiwanese subspecies formosanus Rothschild, 1899 and the Peninsular subspecies malaiianus Frühstorfer, 1902 differ mainly in the female, the males having no consistent distinctive characters, differing mainly in overall size (see plates in Rumbucher \& von Knötgen 1999; Matsuka 2001; d'Abrera 2003).

Among females of T. brookiana, subsp. mollumar has the least prominent whitish streaks on the forewing apex, which start from vein 7. The subspecies trogon has more prominent streaks, starting from either vein 6 or 7, while in the subspecies brookiana from Borneo the white is even more prominent. The subspecies albescens from western Peninsular Malaysia has the most extensive white markings of all the subspecies. Ground colour differences are also an important distinguishing character between the subspecies albescens and brookiana (d'Abrera 2003).

\section{Available molecular data}

Based on a comparison of six DNA sequences of Trogonoptera available in GenBank, differences between taxa at the molecular level are very small ranging from 0.2 to $1.3 \%$ in the ND5 and COI genes. Even differences between T. brookiana (Sumatra, GenBank EF514439, photograph in BOLDSYSTEMS) and T. trojana (Staudinger, 1889) are extremely small, that is six to eight base pairs within 596 base pairs in the COI gene, while different specimens of T. trojana (Philippines, EF514444 and EF514436, photographs in BOLDSYSTEMS) differ by four base pairs. Two specimens of $T$. brookiana from Cameron Highlands, Peninsular Malaysia (AB084428; AB044648, photograph made available to us by S. Morinaka) differ from each other in three out of 877 base pairs in the ND5 gene but differ from a

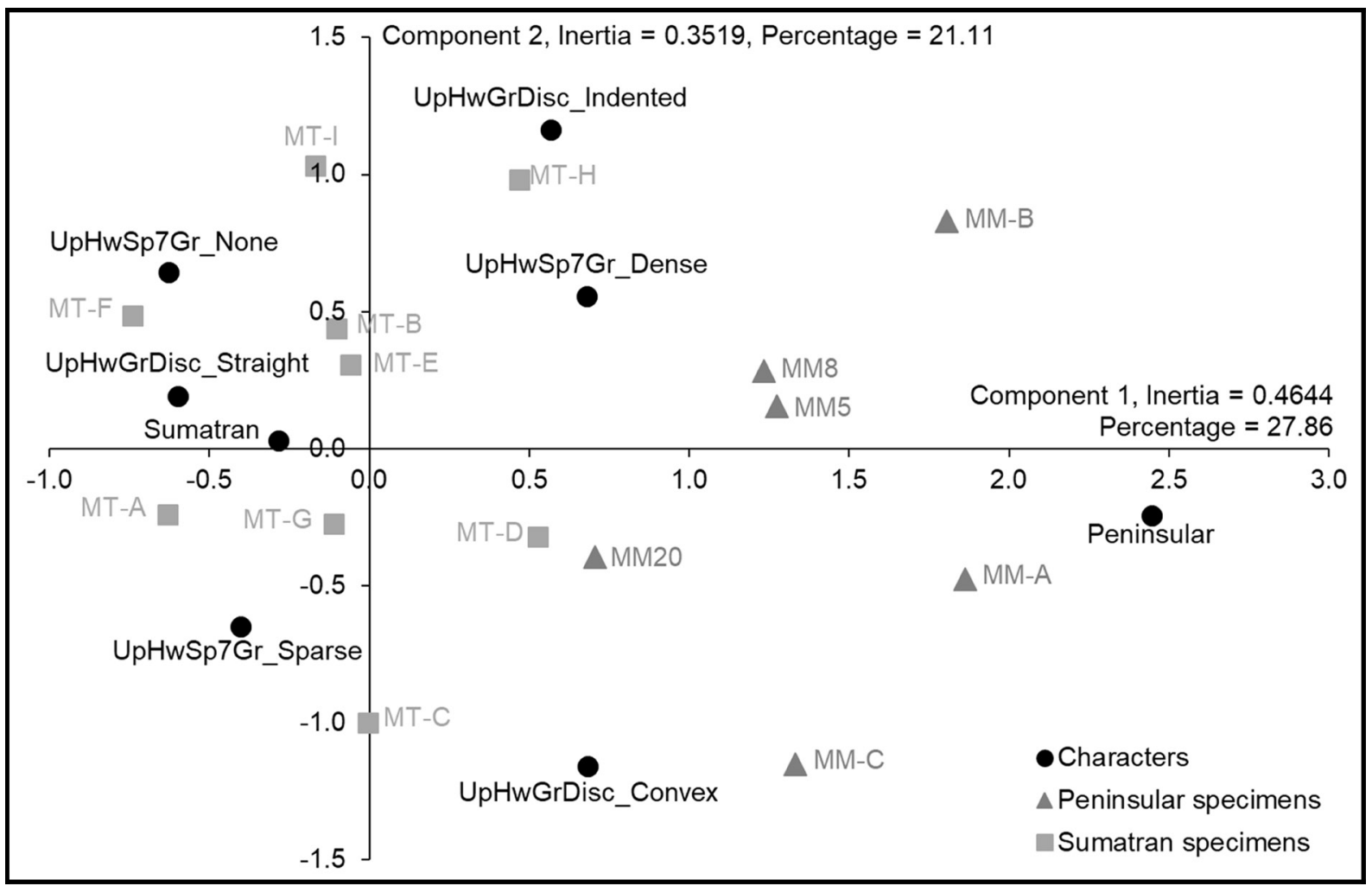

Fig. 6. Two-dimensional plot of correspondence analysis components 1 and 2 for males. Specimens with identical coordinates are grouped together (e.g., MT-A = male, Sumatra, group A; MM-A = male, Peninsular Malaysia, group A). 
specimen listed as T. brookiana from Padang, Sumatra (AB044647) in only two to three base pairs out of 813. These can be inferred from their localities of origin to be subsp. albescens and subsp. trogon, respectively. The very slight differences within and between species therefore make it highly unlikely that common molecular techniques will provide sufficient resolution to answer questions about the subspecific status of populations of T. brookiana.

\section{Ecological differences}

The males of the Sumatran population have been reported to regularly visit a hot sulphur spring (Nicéville \& Martin 1895). However, they do not congregate in numbers (Haugum \& Low 1982). Judging from the disproportionate numbers of Sumatran males in collections, the habit of visiting wet ground must be very well developed even though they do not congregate in groups like the males of the western peninsular subspecies albescens, which has a similar composition of the sexes in collections.

The behaviour of the Sumatran population described by Nicéville \& Martin has neither been reported in the eastern population in the Peninsula nor seen in the first and second authors' extensive observations in its habitat, along rivers or other suitable puddling sites. However, we have occasionally observed it landing and sometimes circling and landing multiple times, always briefly, along rivers or on wet ground along forest roads. A similar behaviour has been seen by other field observers (C.Y. Chong pers. com.; S.K. Khew pers. com.). Therefore, the eastern peninsular population differs greatly from the Sumatran population in this behavioural character.

\section{Taxonomic status of mollumar}

Considering the morphological differences between both sexes and especially the females of the two populations, as well as the comparative differences between other populations already recognised as subspecies, we consider the eastern peninsular population a valid subspecies, mollumar, distinct from the Sumatran subspecies trogon. This conclusion is also supported by differences in behaviour and a geographical separation of the two subspecies.

\section{Diagnoses: mollumar and trogon}

Like the males of most subspecies of T. brookiana, the males of the subspecies mollumar and trogon are not readily differentiable. The females of both subspecies mollumar and trogon are differentiable from other subspecies by the very much reduced subapical white streaks on the forewing and by more extensive green scaling on the upperside of the forewing and hindwing, resulting in at least five long green arrow-shaped markings on the forewing upperside (Figs 2A, C, 4A-B), in comparison to two or three, or sometimes four in most other subspecies. A sixth green arrow-shaped marking is sometimes reduced to just streaks above and below vein six (Figs 2A, C, 4A-B), and a seventh, if present, is reduced to a green streak below vein seven (Figs 2A, G, 4A). The females of the subspecies cardinaali Haugum \& Low, 1982 and jikoi Kobayashi, 1986 have a fifth green arrow-shaped marking but of much shorter length as these subspecies have more reduced green markings on the upperside than the subspecies mollumar and trogon.

The following diagnoses separate mollumar and trogon.

Trogonoptera brookiana mollumar d'Abrera, Doggett \& Parker, 1976 Figs 2A-B, 3A, 4A, C

Trogonoptera brookiana mollumar d'Abrera, Doggett \& Parker, 1976: 22-23; genitalia figured, p. 24.

Ornithoptera brookeana - Distant 1882-1886: 330-331 (pro parte: Johore). — Fickert 1889: 749-753 (pro parte: Johore). 
Trogonoptera brookiana trogon - Corbet \& Pendlebury 1956: 92. - Eliot 1959: 372. - Eliot 1973: 175-176. - Fleming 1975: 15; female figured, pl. 2. - Haugum \& Low 1982: 56-60; genitalia figured, text-fig. 19B, p. 45, text-fig. 29D-F, p. 57, text-fig. 30, p. 58; distribution, p. 56 (pro parte: Peninsular Malaysia; synonymy inferred, considered to be a locality form). - Eliot 2006: 5.

Trogonoptera brookeana - Rippon 1906: 2-4 (pro parte: Johore).

Trogonoptera brookiana mollumar - Eliot in Corbet \& Pendlebury 1978: 67; checklist, p. 421. d'Abrera 1982: 4; holotype and allotype figured, p. 5. - Tsukada \& Nishiyama 1982: 235-236; male and female figured, pl. 32, p. 56. - Fleming 1983: 15; female figured, pl. 2, P1B. Matsuka 2001: 210; checklist, p. 347; male and female figured, p. 210. — d'Abrera 2003: 172174; holotype, allotype and one male figured, p. 175; genitalia figured, p. 314 (status formally revised).

Troides (Trogonoptera) brookiana trogon - Eliot in Corbet \& Pendlebury 1992: 59-60; checklist, p. 394; female figured, pl. 1 (formal synonymy).

\section{Material examined}

Holotype

MALAYSIA • đ̊; Peninsular Malaysia, Johore, Ulu Sedili; 17 Feb. 1974; V. Doggett leg.; BMNH(E) 1420520.

\section{Paratype (allotype)}

MALAYSIA • 1 क; same collection data as for holotype; 29 Aug. 1971; N. Parker leg.; BMNH(E) 1420526.

\section{Additional material ${ }^{*}$}

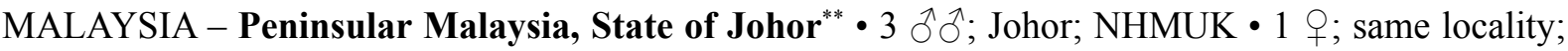

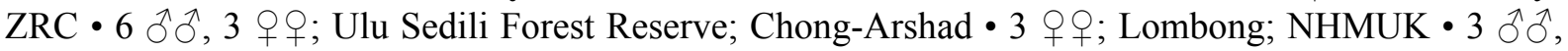

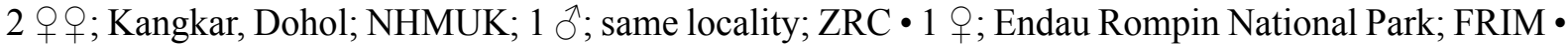

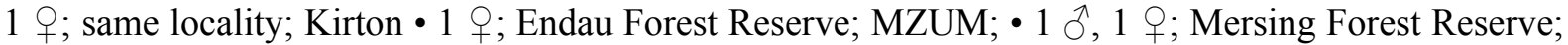

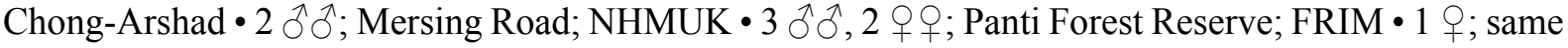
locality; Chong-Arshad $\bullet 1$; Kota Tinggi; NHMUK. - Peninsular Malaysia, State of Pahang 1 $ᄋ$; Rompin Endau; FRIM. - Peninsular Malaysia, State of Terengganu** ${ }^{*} \hat{\delta}$; Jengai Permanent Forest Reserve, near Bukit Lentur; Chong Arshad.

*Label data is shortened for brevity and may vary in detail between specimens from the same general locality. Localities have been georeferenced where possible and are grouped regionally to show geographical coverage, based on the distribution shown in Fig. 1. Regional groupings in bold typeface are not necessarily part of the label data.

${ }^{* *}$ Johor and Terengganu: also spelt Johore and Trengganu, respectively, especially in older labels and literature.

\section{Female}

Almost always identifiable by the entirely black ground colour on the upperside in which the outer areas of both wings barely contrast with the veins and with the black forewing cell (Figs 2A, 4A). Hindwing upperside with more extensive green scaling than in the subspecies trogon, extending to about half to two thirds of the length of space 4 (Figs 2A, 4A). Forewing upperside with more extensive green scaling than in the subspecies trogon, the green arrow-shaped markings slightly longer and reaching nearer the wing margin, especially along vein 2 , and with the black ground colour behind the arrowheads sometimes just perceptibly narrower than in trogon (Figs 2A, 4A). Forewing underside green scales in space 4 always present, forming a broken patch (Fig. 2E) or sometimes entire patch (Figs 2B, D) of green scales. Forewing upperside with a green streak below vein 7 , its scaling usually dense (Figs 2A, G, 4A). 
Male

Upperside hindwing green disc on average more extensive than in the subspecies trogon (Figs 3A, 4C), with the outer margin usually convex (Figs 3A-B, 4C) or slightly indented (Fig. 3C-D). Forewing upperside with more extensive green scaling than in trogon as in the female (Figs 3A, 4C). Green scales always present in space 7 of the hindwing upperside, and usually dense (Figs 3A, F-G, 4C). Not reliably distinguishable from males of the subspecies trogon.

\section{Range}

Eastern Johor northward to southernmost Pahang, and central to southern Terengganu in Peninsular Malaysia (Fig. 1).

Trogonoptera brookiana trogon (Vollenhoven, 1860)

Figs 2C, 4B, D

Papilio trogon Vollenhoven, 1860: 69-70; male figured, pl. 6.

Ornithoptera brookiana +-variety eleanor Walker, 1889: 75-77 (locality not stated).

Papilio brookeanus - C. \& R. Felder 1864: 292, 334 (pro parte: Sumatra; Papilio trogon synonymised with Papilio brookeanus).

Ornithoptera brookeana - Distant 1882-1886: 330-332 (pro parte: Sumatra). — Fickert 1889: 749-753 (pro parte: Sumatra). - Hagen 1894: 18 (pro parte: Sumatra).

Papilio brookeana - Snellen \& Snelleman 1892: 6, 24.

Troides brookianus brookianus - Rothschild 1895: 198-199 (pro parte: Sumatra).

Troides brookianus brookianus +-aberration eleanor - Rothschild 1895: 199.

Trogonoptera brookeana - Kirby 1896: 259-263 (pro parte: Sumatra). — Rippon 1906: 2-4 (pro parte: Sumatra).

Trogonoptera brookeana + var. eleanor - Rippon 1906: 1, 4 (redescription); distribution mentioned, p. 127 ("Sumatra"); female figured, pl. 26, figs 5-6; distribution map erroneously figured as Borneo, map 6, pl. 43.

Papilio brookiana trogon - Jordan 1908: 17-18 (status revised).

Papilio brookiana trogon, syn. eleanor - Jordan 1908: 17-18 (synonymised, "trogon Voll. (q-eleonor Walk.)", misspelled); female figured (pl. 7c).

Trogonoptera brookiana trogon - Tsukada \& Nishiyama 1982: 235-236; male and female figured, pl. 32, p. 56; genitalia figured, p. 237. — d'Abrera 1982: 4; male figured, p. 5. — Haugum \& Low 1982: 51-56; male figured, pl. 1, no. 2; female figured, pl. 2, no. 4; larva figured, text-fig. 18, p. 42; male genitalia figured, text-fig. $19 \mathrm{D}$, p. 45 , text-fig. 27 , p. 54 , text-fig. $29 \mathrm{~A}-\mathrm{C}$, p. 57 , text-fig. $30 \mathrm{~A}$, C, p. 58; distribution map figured, text-fig. 25, p. 51 (Sumatra). - Matsuka 2001: 210; checklist, p. 347; male and female figured. — d'Abrera 2003: 170; male and female figured, p. 171; genitalia figured, p. 314.

Trogonoptera brookiana trogon, syn. eleanor - Haugum \& Low 1982: 54-55 (nomen dubium recommended, but regarded as synonym of trogon for 'convenience'). - Matsuka 2001: 347 (checklist).

Trogonoptera brookiana brookiana -f. eleanor - d'Abrera 2003: 168.

\section{Material examined}

Syntypes

INDONESIA・ 2 ○ðં; Sumatra; 1859; Ludeking leg.; RMNH. 


\section{Additional material}

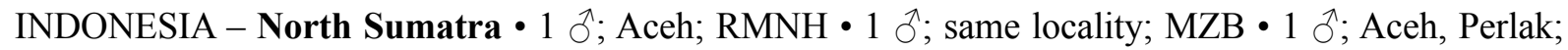

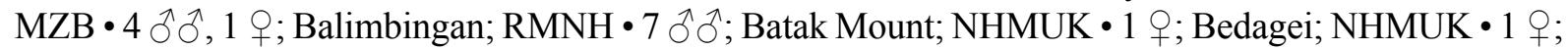

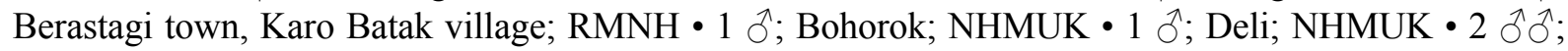

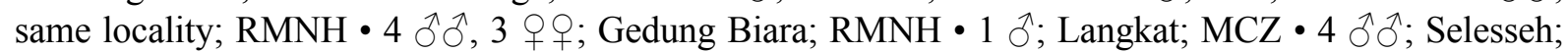

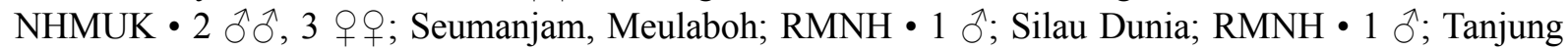

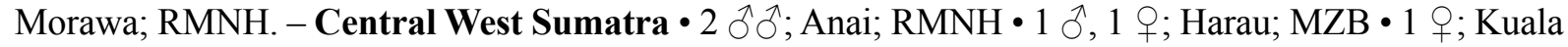

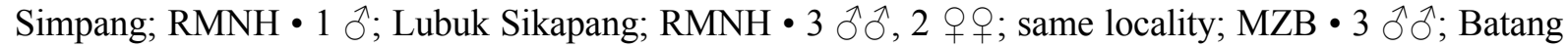
Proepoe, Padang Bovenland; NHMUK • 1 क ; Padang Benedenl; NHMUK • 55 $\lesssim$; Padang; RMNH

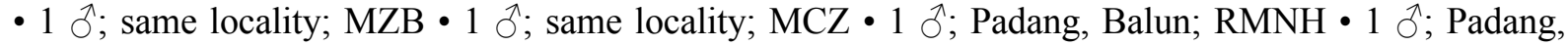

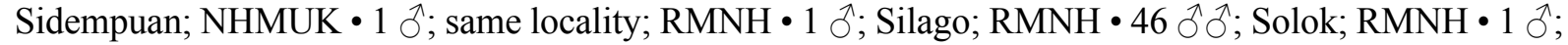

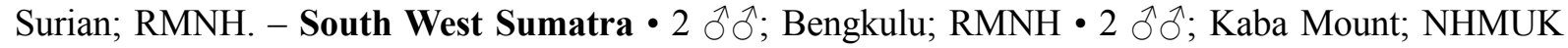

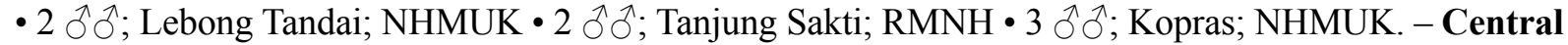

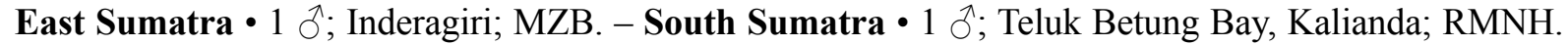

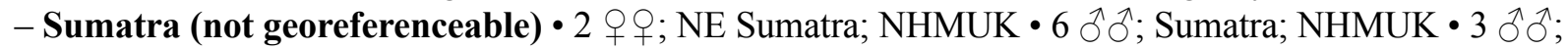

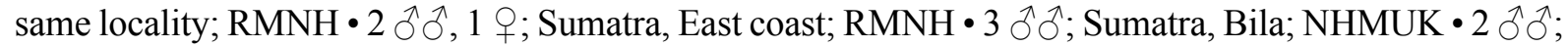

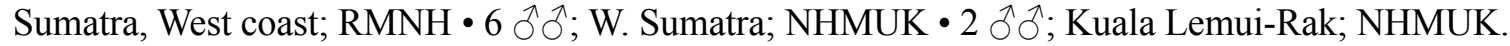

* See note for additional material of T. brookiana mollumar, which is also applicable here for T. brookiana trogon.

\section{Female}

Almost always identifiable by the brown to dark brown ground colour of the outer areas on the upperside of both wings, which are paler than the base of the dark forewing cell and dark veins, and especially contrasting at the forewing cell end and the distal end of the forewing (Figs 2C, 4B). Hindwing upperside with less extensive green scaling than in the subspecies mollumar, extending to about one third to half the length of space 4 (Figs 2C, 4B). Forewing upperside with less extensive green scaling than in the subspecies mollumar, the green arrow-shaped markings slightly shorter and ending further from the wing margin, especially along vein 2, and with the dark brown ground colour behind the arrowheads sometimes just perceptibly wider than in mollumar (Figs 2C, 4B). Forewing underside space 4 usually with just sparse green scaling (Fig. 2F) and sometimes without green scales, but occasionally with a broken patch of scales (Fig. 2E). Forewing upperside without green scaling below vein 7 or, more commonly, with sparse scaling (Fig. 2H), and sometimes with a densely-scaled green streak (Fig. 2G).

\section{Male}

Green disc on hindwing upperside on average less extensive than in the subspecies mollumar, with the outer margin variable, but straight (Figs 3E, 4D) in about half of males. Forewing upperside with less extensive green scaling (Fig. 4D) than in mollumar, as in the female. Green scaling in space 7 on the hindwing upperside variable, not always present, often sparse (Fig. 3H-I). Not reliably distinguishable from males of the subspecies mollumar.

\section{Range}

Sumatra Island, excluding small neighbouring islands, occurring in the foothills, especially in the northeast and central to south-central west, but with occasional coastal occurrences in the south, south-central east and north (Fig. 1).

\section{Discussion}

\section{Status of the taxon mollumar}

Haugum \& Low (1982) examined many males from Sumatra but only 10 of the more rarely collected females and just a few males and females from the Peninsula. They gave exclusive forewing length 
ranges for Sumatran and Peninsular males but inexplicably said they fully overlap. We found a significant difference among males, but a large overlap. They also examined other characters by subjective judgement without quantification. Perhaps because of this and limited availability of specimens from the Peninsula, they did not perceive adequate differences between the Sumatran and Peninsular specimens.

In the current study, we examined a larger sample and larger number of characters quantitatively using measurements and scores. Discriminant function analysis, correspondence analysis and significance tests all showed that Sumatran and Peninsular specimens differ morphologically in both sexes, but especially in the female. Females could almost always be diagnosed by their distal ground colour (Figs 2A, C, 4A-B) and, where there was doubt, could be diagnosed by a combination of characters. The differences between the Sumatran and eastern Peninsular populations, though small, are comparable in magnitude and consistency to differences between other subspecies of T. brookiana of undisputed status. We therefore conclude that mollumar merits the status of a subspecies distinct from trogon, a conclusion supported by differences in their ecology and behaviour, which, as pointed out by Parsons (1996), can be useful in differentiating taxa.

\section{Status of the taxon eleanor}

The nominal taxon eleanor was described by Walker (1889). It was described as a female variety of Trogonoptera brookiana ("Ornithoptera brookiana"), without information on type locality, and conforms in the description of its morphology with the females of subsp. trogon and subsp. mollumar. Rippon (1906: 1, 4, pl. 26, figs 5-6), who later received two females from Walker, redescribed and figured the taxon, but it is not possible to ascertain the locality of origin from the description or illustrations. Rippon (1906: 127), however, listed the locality as Sumatra, and his account of the specimens he received suggests that he received from Walker what would appear to be the only specimen on which Walker based his description, which lacked antennae (cf. Walker 1889: 77). Inexplicably, the maps of Rippon (1906: map 6, pl. 43) show eleanor in Borneo and absent from Sumatra, but no other specific mention is made of Borneo as a locality for eleanor, contrary to what is stated by Haugum \& Low (1982). Our view is that eleanor, which is senior to mollumar, is best treated as a synonym of trogon to which it is junior, just as it has been treated by Jordan (1908) and Ohya (in Matsuka 2001). All available evidence suggests that it is from Sumatra. No forms resembling trogon or mollumar have ever been recorded from Borneo. The absence of eleanor from Rippon's Sumatran map and its inclusion in his Bornean map is clearly a mix-up on his part, and may have led d'Abrera (2003) to treat eleanor as a female-form of the nominate Bornean race brookiana. Therefore, we do not think it necessary to regard eleanor as a nomen dubium as suggested by Haugum \& Low (1982), even though we are also unable to trace the type of eleanor. Rippon's collection in the National Museum of Wales, Cardiff does not have specimens that could correspond with Walker's (M. Wilson pers. com.). The type may remain in Walker's collection, for which we have been unable to find information on its whereabouts.

\section{Recognised subspecies of Trogonoptera brookiana}

The following subspecies of T. brookiana are recognised:

Trogonoptera brookiana (Wallace, 1855)

T. b. brookiana (Wallace, 1855) - Borneo

T. b. haugumei Parrott, 1991 - East Kalimantan

T. b. bosuangi Schäffler, Rumbucher \& Dufek, 2014 - Banggi Island

T. b. natunensis (Rothschild, 1908) - Natuna Island

T. b. albescens (Rothschild, 1895) - Western Peninsular Malaysia

T. b. mollumar d'Abrera, Doggett \& Parker, 1976 - Eastern Peninsular Malaysia

T. b. trogon (Vollenhoven, 1860), syn. eleanor (Walker, 1889) - Sumatra

T. b. cardinaali Haugum \& Low, 1982 - Lingga Islands 
T. b. jikoi Kobayashi, 1986 - Tuangku Island

T. b. toshikii Kobayashi, 1991, syn. apolloniae Neukirchen, 1992 - Mentawai Islands

T. b. mariae Neukirchen, 1993, syn. akikoae Morita, 1994 - Batu Islands

\section{Status of the taxa walshi and walshoides}

Haugum \& Low (1982) described two male 'forms' under the subspecies trogon namely walshi and walshoides with 'types' designated in the RMNH, Leiden. In the specimens on which the descriptions are based, "walshi" has the basal half of the veins of the forewing bordered by semi-translucent dull brown scales instead of the usual black. The form "walshoides" has a similar colouration but more extensive, covering the whole basal halves of the forewing and hindwing, instead of occurring only around the basal veins of the forewing. However, the extent and intensity of the abnormal colouration is variable between several specimens in RMNH, sometimes being restricted to the basal veins or extreme base and sometimes extending to over two thirds of the wings, and may even be asymmetric. The iridescent blue scales described by Haugum \& Low (1982) around the outer margins of the abnormally coloured area were not seen in the specimens examined. The characters used in describing these 'forms' are actually artefacts of chemically induced discolouration. When examined under a microscope, the antero-lateral margins of the scales in the discoloured areas of the wings can be seen to be curled or rolled inwards, sometimes with the scales raised and rolled to a conical point, instead of lying flat as in normal scales. The distribution of the scales in the basal half of the wings and sometimes surrounding only the basal veins of the forewing, its variability and sometimes asymmetric pattern, is consistent with a chemical killing agent or preservative that was absorbed by the body and dispersed into the wings through the veins from which it would have seeped into adjacent wing membranes and scales. Chemicals such as ether, chloroform, carbon tetrachloride, hydrogen cyanide, ammonia and ethyl acetate have been used in the past as killing agents and some are known to produce chemically-induced wing discolouration after prolonged exposure (Salmon 2000). We therefore view that "walshi" and "walshoides" are not valid biological forms. Since infra-subspecific names are not regulated by the ICZN, these named forms do not become available names and are not included in the synonymy.

\section{Acknowledgements}

This study was funded by the Malaysian Economic Planning Unit, Ministry of Natural Resources and Environment, and University of Malaya (Postgraduate Research Fund grant no. PV131/2012A). We thank Chow-Yang Chong for useful suggestions on subspecies differences and for access to specimens and reference material in the Chong-Arshad collection. We are grateful to the following museums and their staff for access to the collections and assistance during our visits: Blanca Huertas, Geoffrey Martin, Alessandro Giusti, Alberto Zilli (NHMUK), Rob de Vos, Eulàlia Gassó Miracle (RMNH), A. Sasekumar, Thary Gazy, Amni Bazilah Sulaiman (MZUM), Naomi Pierce, Rod Eastwood (MCZ), Peter Ng, Sin-Khoon Khew, Wei-Song Hwang, Hui-Kheng Lua (ZRC), Djunijanti Peggie (MZB), Izfa Hazmi and Ganaswary Aruchunnan (Centre for Insect Systematics, Universiti Kebangsaan Malaysia). We also thank Rob de Vos and Eulàlia Gassó Miracle (RMNH) for useful information on chemicals that may affect butterfly scales, Michael Wilson (National Museum of Wales, Cardiff) for examining specimens in the Rippon collection, Steve Marshall (University of Guelph), Valerie Levesque-Beaudin (Biodiversity Institute of Ontario, University of Guelph) and S. Morinaka for helping us to source the voucher specimens listed in GenBank, Carla Penz (University of New Orleans) and Konrad Fieldler (Universität Wien) for useful comments on an early draft of this article, and Henry Barlow for use of reference material in the Cowan Library.

\section{References}

CITES. 2017. Convention on International Trade in Endangered Species of Wild Flora and Fauna: Appendix II. Available from http://www.cites.org/eng/app/appendices.php [accessed 22 Dec. 2017]. 
Cognato A.I. 2006. Standard percent DNA sequence difference for insects does not predict species boundaries. Journal of Economic Entomology 99: 1037-1045. https://doi.org/10.1093/jee/99.4.1037

Corbet A.S. \& Pendlebury H.M. 1956. The Butterflies of the Malay Peninsula. $2^{\text {nd }}$ ed. Oliver and Boyd, Edinburgh and London.

Corbet A.S. \& Pendlebury H.M. 1978. The Butterflies of the Malay Peninsula. $3^{\text {rd }}$ ed. Revised by Eliot J.N. Malayan Nature Society, Kuala Lumpur.

Corbet A.S. \& Pendlebury H.M. 1992. The Butterflies of the Malay Peninsula. $4^{\text {th }}$ ed. Revised by Eliot J.N. Malayan Nature Society, Kuala Lumpur.

d'Abrera B. 1982. Butterflies of the Oriental Region. Vol. Part 1: Papilionidae, Pieridae and Danaidae. Hill House, Victoria, Australia.

d'Abrera B. 2003. Birdwing Butterflies of the World. New and revised edition. Hill House Publishers Pty Ltd, Victoria, Australia.

d'Abrera B., Doggett V. \& Parker N. 1976. A new race of Trogonoptera brookiana Wallace (Lepidoptera: Papilionidae) from West Malaysia. The Victorian Naturalists 93: 21-24.

Distant W.L. 1882-1886. Rhopalocera Malayana: A Description of the Butterflies of the Malay Peninsula. West, Newman and Co., London. https://doi.org/10.5962/bhl.title.8806

Eliot J.N. 1959. New or little known butterflies from Malaya. Bulletin of the British Museum (Natural History) Entomology 7: 371-391.

Eliot J.N. 1973. Letters to the editor: Rajah Brooke's Birdwing in Trengganu. Malayan Nature Journal 26: $175-176$.

Eliot J.N. 2006. Updating The Butterflies of the Malay Peninsula. Edited, enlarged and prepared for publication by Barlow H., Eliot R., Kirton L.G. \& Vane-Wright R.I. Malayan Nature Journal 59: 1-49.

Felder C. \& Felder R. 1864. Species Lepidopterorum hucusque descriptae vel iconibus expressae in seriem systematicam digestae. Verhandlungen der kaiserlich-königlichen zoologisch-botanischen Gesellschaft in Wien 14: 289-378.

Fickert C. 1889. Ueber die Zeichnungsverhältnisse der Gattung Ornithoptera. Zoologische Jahrbücher. Abtheilung für Systematik, Geographie und Biologie der Thiere 4: 692-770.

Fleming W.A. 1975. Butterflies of West Malaysia and Singapore. Vol. 1. Longman Malaysia Sdn. Berhad, Kuala Lumpur.

Fleming W.A. 1983. Butterflies of West Malaysia and Singapore. $2^{\text {nd }}$ ed. Revised by Mc Cartney A. Longman Malaysia Sdn. Berhad, Selangor.

Hagen B. 1894. Verzeichniss der von mir auf Sumatra gefangenen Rhopalocera. Deutsche Entomologische Zeitschrift 7: 1-41.

Haugum J. \& Low A.M. 1982. A Monograph of the Birdwing Butterflies, the Systematics of Ornithoptera, Troides and Related Genera. Vol. 2, Part 1: The Genera Trogonoptera, Ripponia and Troides. E.J. Brill/ Scandinavian Science Press Ltd., Leiden and Copenhagen.

Jordan K. 1908. Family Papilionidae. In: Seitz A. (ed.) Macrolepidoptera of the World (9 ed.): 11-118. E. Le Moult, Paris.

Kirby W.F. 1896. A Handbook to the Order Lepidoptera. Part I, vol. II. Edward Lloyd, Limited, London. https://doi.org/10.5962/bhl.title.23911

Kirton L.G. 1991. Butterflies in Peninsular Malaysia. In: Kiew R. (ed.) The State of Nature Conservation in Malaysia: 105-110. Malayan Nature Society, Kuala Lumpur. 
Kirton L.G. 2014. A Naturalist's Guide to the Butterflies of Peninsular Malaysia, Singapore and Thailand. John Beaufoy Publishing Limited, Oxford.

Matsuka H. 2001. Natural History of Birdwing Butterflies. Matsuka Printing Co, Tokyo. (Checklist of Birdwing Butterfly authored by T. Ohya).

Nicéville L. de \& Martin L. 1895. A list of the butterflies of Sumatra with especial reference to the species occurring in the north-east of the Island. Journal of the Asiatic Society of Bengal 64: 357-555.

Panchen A.L. 1980. Notes on the behaviour of Rajah Brooke's birdwing butterfly, Trogonoptera brookiana brookiana (Wallace), in Sarawak. The Entomologist's Record and Journal of Variation 92: 98-102.

Parsons M.J. 1996. Gondwanan evolution of the Troidine swallowtails (Lepidoptera: Papilionidae): Cladistic reappraisals using mainly immature stage characters, with focus on the birdwings Ornithoptera Boisduval. Bulletin of the Kitakyushu Museum of Natural History 15: 43-118.

Phon C.-K. \& Kirton L.G. 2009. Conservation of the Rajah Brooke's birdwing, one of Malaysia's natural wonders. Conservation Malaysia Bulletin 10: 2-3.

Phon C.-K., Kirton L.G. \& Wong S. 2011. A glimmer of hope for the Rajah Brooke's birdwing. Malaysian Naturalist 65-1: 24-25.

Rippon R.H.F. 1906. A Monograph of the Papilionine Tribe Troides of Hübner, or Ornithoptera [birdwing butterflies] of Boisduval. Vol. 2. London. https://doi.org/10.5962/bhl.title.60897

Rothschild W. 1895. A revision of the Papilios of the eastern hemisphere, exclusive of Africa. Novitates Zoologicae 2: 167-463.

Rumbucher K. \& von Knötgen B. 1999. Butterflies of the World. Part 6, Papilionidae III, Troides I. Bauer E. \& Frankenbach T. (eds). Goeke \& Evers, Keltern.

Salmon M.A. 2000. The Aurelian Legacy - British Butterflies and their Collectors. With Additional Material by Marren P. and Harley B. University of California Press, Berkeley and Los Angeles, California.

Snellen P.C.T. \& Snelleman F. 1892. Lepidoptera. Natuurlijke Historie 4: 4-92.

Tsao W.-C. \& Yeh W.-B. 2008. DNA-based discrimination of subspecies of Swallowtail butterflies (Lepidoptera: Papilioninae) from Taiwan. Zoological Studies 47: 633-643.

Tsukada E. \& Nishiyama Y. 1982. Butterflies of the South East Asian Islands. Vol. 1: Papilionidae. Plapac Co Ltd, Tokyo, Japan.

Vollenhoven S.C.S.V. 1860. Description d'une nouvelle espèce de lépidoptère du genre Papilio, suivie d'une énumération des espèces de ce genre, qui se trouvent au Musée royal des Paysbas à Leide. Tijdschrift voor Entomologie 3: 67-89.

Walker F.A. 1889. Description of a variety of Ornithoptera brookiana (female). The Transactions of the Entomological Society of London: 75-77. https://doi.org/10.1111/j.1365-2311.1889.tb02697.x

Manuscript received: 22 October 2018

Manuscript accepted: 27 May 2019

Published on: 13 August 2019

Topic editor: Gavin Broad

Desk editor: Pepe Fernández 
Printed versions of all papers are also deposited in the libraries of the institutes that are members of the EJT consortium: Muséum national d'Histoire naturelle, Paris, France; Meise Botanic Garden, Belgium; Royal Museum for Central Africa, Tervuren, Belgium; Royal Belgian Institute of Natural Sciences, Brussels, Belgium; Natural History Museum of Denmark, Copenhagen, Denmark; Naturalis Biodiversity Center, Leiden, the Netherlands; Museo Nacional de Ciencias Naturales-CSIC, Madrid, Spain; Real Jardín Botánico de Madrid CSIC, Spain; Zoological Research Museum Alexander Koenig, Bonn, Germany; National Museum, Prague, Czech Republic. 